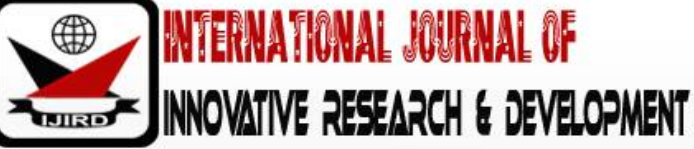

ISSN 2278 - 0211 (Online)

\section{Effectiveness of Strategies Used by Heads of Schools in Enhancing Chemistry Performance in form Four National Examinations in Hai District, Tanzania}

\author{
Bernard Fanyisa \\ Former Master, Department of Education, Mwenge Catholic University, Tanzania \\ Joseph M. Malusu \\ Associate Professor, Department of Education, Mwenge Catholic University, Tanzania
}

\begin{abstract}
:
The study was on effectiveness of strategies of heads of schools in enhancing chemistry performance in form four national examinations in Hai district-Tanzania. Target population included: heads of schools, chemistry teacher, form four chemistry students, zonal chemistry quality assurance officers and district secondary education officer (dseo). Both probability and nonprobability sampling were used to obtain samples, stratified sampling followed by simple random sampling procedures were used to obtain schools. Questionnaires were administered to heads of schools chemistry teachers and students, for dseo and chemistry quality assurance officer interview guide were used. Document analysis guide collected secondary data. Split-half technique was used to obtain the reliability of the instruments. Statistical package for social sciences (spss) analyzed quantitative data while qualitative data were presented in narration form. Test for hypothesis was done using; pearson's product moment coefficient. The study found that :(i) heads of schools used varieties of strategies some were effective and others not. The findings showed that private secondary schools were better in utilizing effective strategies than public schools (ii) chemistry teachers and students used varieties of teaching and learning strategies in classrooms some were more used and others less used due to lack of teaching and learning resources. The study recommended that heads of schools should use effective strategies frequently and support teachers and students in enhancing chemistry performance. There was a statistically significant relationship between mean scores of effective strategies used by heads of schools and students chemistry performance in hai district.
\end{abstract}

Keywords: Chemistry, Private secondary schools, Public secondary schools, Heads of schools, Effectiveness, Strategies, Fnhance nerformance. Performance.

\section{Background to the Problem}

The UNESCO (2005) argues that the level of a country's education is one of the key indicators of its level of development. This concern for quality education is reflected in the inauguration of Education for All (EFA) in Jomtien Thailand in 1995 and Dakar in 2000. Development of science and technology especially in developing nations demands the preparation of skilled individuals in science disciplines from lower levels of academic and skill training.

In Tanzania Chemistry is among science subject taught in secondary schools' curriculum. Chemistry is seen by society as the foundation of technological knowledge that is vital in social- economic development of the nation. Chemistry has been identified as a very important science subject and its importance in scientific and technological development of any nation has been widely reported. It has been a pre-requisite subject for offering most science-oriented courses in the tertiary institution and this calls for the need in teaching it effectively (Adesoji \& Olatunbosun, 2008). For example, a good secondary school education pass grade in Chemistry is a prerequisite for joining the prestigious courses in Sciences such as Medicine, Architecture and Engineering professional courses (Mususya, 1992). It is therefore important that performance in Chemistry should be of high levels (Aluko, 2008).

Due to the importance of Chemistry subject in Tanzania the government has made some efforts in improving performance in Chemistry in secondary schools for instance introduction of Big Results Now (BRN) and changes in curriculum from content based to competence-based curriculum. Despite all efforts the performance of Chemistry in form four National examinations in schools particularly in public schools has not yet yielded significant changes.

\begin{tabular}{|c|c|c|c|c|c|}
\hline Years & $\mathbf{2 0 1 1}$ & $\mathbf{2 0 1 2}$ & $\mathbf{2 0 1 3}$ & $\mathbf{2 0 1 4}$ & $\mathbf{2 0 1 5}$ \\
\hline Pass rate in \% & 43.10 & 46.00 & 50.19 & 56.73 & 60.11 \\
\hline Failure rate in \% & 56.90 & 54.00 & 49.81 & 43.27 & 39.89 \\
\hline
\end{tabular}

Table 1: Performance in Chemistry CSEE 2011- 2016

Source: (NECTA, 2011-2015) 
Table 1 above shows that performance of Chemistry in Tanzania is improving as the percentage pass rate seems to improve slightly probably due to BRN introduction but still not impressing as per NECTA results form 2011- 2015. Furthermore very few students seem to score good grades which are considered as credit passes for instance according to results in 2012 a total of 75,441 students (44.1\%) passed at grade A - D and among them 49,428 candidates equivalent to $65.5 \%$ scored grade D implying that majority of the candidates passed with lower grade while 84,293(54.00\%) failed completely at F grade. Form four Chemistry graduates with grade D and F in most cases do not qualify for joining Advanced level of secondary education and for most middle colleges training.

Hai is among district whose Chemistry performance is not impressing particularly in public secondary schools, for instance the pass rate of Chemistry in Hai district in the CSEE 2017 was 58\% but when private schools are excluded the pass rate was $46 \%$ that means some schools particularly private are pulling other schools. Furthermore, large number of students with pass rate scores D grade which is a weak pass, for instance in the 2016 Chemistry National examinations in Hai district $69 \%$ of students scored grade D and F and only $31 \%$ of students scored grade A-C which is a credit pass needed for further studies. It implies that the nation is producing incompetent Chemists for that case it forecast the poor and scarce experts in key sectors such as industries, Agriculture, Education Health and threatens country advancement in science and technology.

In attempt to rescue the situations several studies in Tanzania and outside Tanzania have been done on Chemistry performance and instructional leadership in Chemistry performance for instance Out \& Avaa (2007) found that teacher variables, students' variables and environment related variables contribute greatly to the unsatisfactory performance of students in Science. According to Shemhilu (2015) who used students as main respondents raised concerns on factors affecting Chemistry performance in National Examinations which includes insufficient facility distribution and accessibility in secondary schools, problems of enough qualified Chemistry teachers in schools and poor student home support. Questions arises on the Heads of schools supervisory and support to Chemistry teachers and students as whether enables availability of teaching and learning resources and effectively use of the same to enhance Chemistry performance. It appears as if there is ineffective monitoring of teacher's activities, with poor performance appraisal of Chemistry teachers; which often results in poor instructional delivery in schools for instance, Ayeni \& Akinfolarin (2014) noted that to improve student's academic performance, managers are required to improve the administrative strategies in schools. Therefore, Managers must be able to evaluate their teachers in order to ascertain weaknesses of the instructional delivery system which hinder Chemistry performance. Ineffective of the Heads of school's administrative strategies with no doubt hinder Chemistry teaching and learning.

There is a growing concern of the society due to the observation that some of the Heads of schools could not have been using some administrative strategies that could effectively facilitate better Chemistry performance of students in National form four examinations. Ministry of Education and Vocational Training in Tanzania (MoEVT, 2013) emphasizes heads of schools to improve effectiveness of supervision in schools. Though Head of schools have been providing leadership in the school system but Supervision of school and classroom instructions is seemingly not taken seriously among heads of schools. perhaps some administrative strategies that could lead to the achievement of Chemistry objectives have not been provided by many Heads of schools. According to Galabawa, (2001) Tanzania is experiencing a lot of problems in schools. One could be interested to know whether the strategies used by heads of schools as among the supervisors to influence student's performance particularly in Chemistry subject. One can ask are the Chemistry teachers well supervised accordingly by the Heads of schools? Are there enough trained teachers and heads of schools to make use of effective strategies in chemistry? Are there strategic plans implemented effectively to enhance the Chemistry performance? It seems instructional leadership is not a function that takes up the majority of heads of school's time. Literature has shown that HoSs in Africa rarely engage in Instructional Leadership (World Bank, 2010). This background prompted the undertaking of this study on Effectiveness of Heads of school Strategies used to enhance students Chemistry performance in form four National examinations in Hai district- Tanzania.

\subsection{Statement of the Problem}

Performance of students in Chemistry has been; slightly below and above average pass rate of $50 \%$ for five years (Table 1) with a high number of students failing to score credit passes, hence raising concerns to educational experts, teachers, parents and students due to the fact that the country will have scarcity of experts in Chemistry related fields which are important for the economic and technological advancement of the nation.

Several studies have been done on performance of Chemistry for instance Shemhilu, (2015), Out \& Avaa (2007), Chemutai (2014), Galabawa, (2001), Martel (2009) revealed that students' academic performance in Chemistry in secondary schools is being affected by a combination of an identified number of problems including inadequate Chemistry teachers, learning and teaching facilities in Chemistry. Mwinyipembe and Orodho (2014) study on administrative and supervisory roles of Quality Assurance and Standard Officers (QASOs) to enhance general schools' performance and not particularly in Chemistry supervisory roles and their impact on student's academic performance in National Examinations. Unfortunately, the strategies used by school's management are not known as to whether those strategies were effective or not. However, most of the studies concentrated on chemistry teachers and students' factors, little has been done on administrative strategies by heads of schools.

The government has given mandate to heads of schools to improve their effectiveness in instructional supervision, despite the power given to heads of schools there is still doubt on school supervision by heads of schools due to unsatisfactory achievement in Chemistry as the strategies has yet yielded the desired students Chemistry performance. This situation prompted the researcher to conduct study on Effectiveness of Strategies used by Heads of schools in enhancing Students performance in Chemistry in Form Four National Examinations - Hai district. 


\subsection{Research Questions}

The study was guided by the following questions:

- How effective are the strategies used by heads of schools to enhance performance in form four national examinations in Hai district?

- To what extent do Chemistry teachers and students use Heads of school's strategies in enhancing students Chemistry performance in form four national examinations in Hai district?

\subsection{Research Hypothesis}

- Alternative hypothesis $\mathrm{H}_{\mathrm{I}}$ : There is a significant relationship between strategies used by Heads of schools in enhancing Chemistry and students Chemistry performance in Form Four National Examinations in secondary schools in Hai district.

\subsection{This Conceptual Framework Was Developed to Guide the Study}

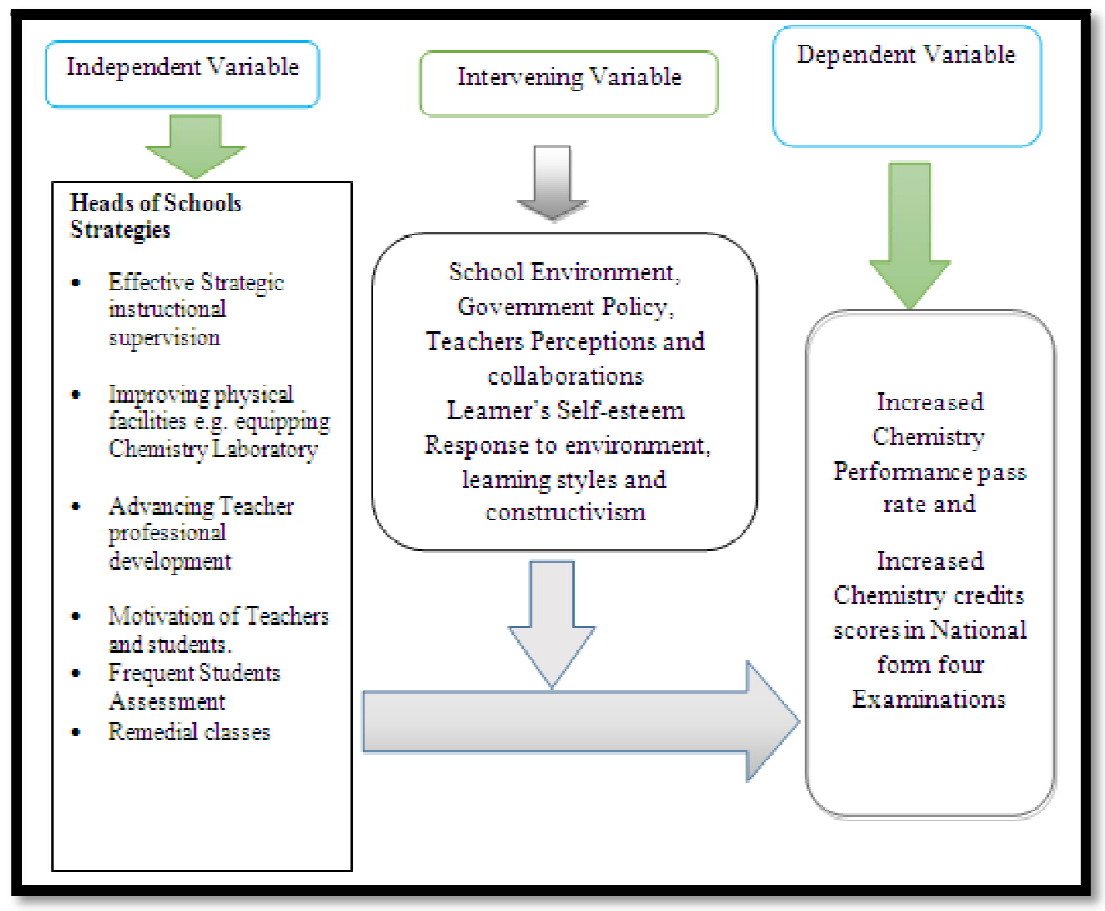

Figure 1: Conceptual Framework

Source: Constructivist Theory by Brunner (1966) and Modified by the Author (2018)

Figure 1 shows a conceptual framework which shows the relationship between three sets of variables in this study the independent variables are conceptualized as the Effective Heads of schools Strategies to enhance Chemistry performance in Form Four National Examinations while dependent variables are conceptualized as academic students' performance in Chemistry which includes increased pass rate and number of students scoring credits passes in Chemistry. Before realization of chemistry performance and increased credits passes in Chemistry some variables interact which includes good school environment, good government policies, teachers' perceptions and collaborations and learner's selfesteem to respond to environment, various learning styles and constructivism approaches to chemistry teaching and learning which are intervening variables.

\section{Literature Review}

\subsection{Review of Empirical Studies.}

The following literatures were reviewed:

Apolline (2014) conducted a study on Motivational Strategies used by Principals in the Management of Schools in Cameroon. The descriptive survey design was used to collect data from a representative sample of the population using questionnaires for teachers and principals. The findings revealed that motivational strategies of principals include those related to empathetic, supportive, caring and just on academic and disciplinary matters; positive leadership Characteristics and transformational leadership style. The findings also revealed that motivation is significant and is positively related to the teaching and learning process. Finally, the economic state of the nation, the character of the school administrator, school physical environment, political image of the nation, location and the financial status of the school are the factors that influence staff motivation.

Researcher findings a very crucial, however the researcher based on motivational strategies which is a single strategy. Comprehensive integrated strategies are needed to be incorporated in order to bring better performance in schools. The motivational strategies used was for general school performance as it has not been specific for the Chemistry subject which means it did not explore the strategies for enhancing Chemistry performance. Furthermore, the study used 
only two categories of respondents and only questionnaires for data collection which might affect the validity and reliability of the findings in terms of triangulation since data from different categories of respondents are more dependable. This inadequacy might affect the generalizing of research findings to the whole population. The current study explored varieties of Heads of school's strategies and its effectiveness in enhancing Chemistry performance. The current study used cross section survey design using varieties of instruments and respondents to examine the Effectiveness of the Heads of schools to enhance Chemistry performance in National form four examinations.

Ayeni \& Akinfolarin (2014) conducted a study on assessing Principals Coordinating and Controlling Strategies for Effective Teaching and Quality Learning Outcome in Secondary Schools in Ondo State, in Nigeria. The study examined the effectiveness of principals coordinating and controlling strategies on teachers' instructional performance and students learning outcome. Descriptive survey research design was adopted for data collection and analysis. Questionnaires were administered for principals and teachers. The result showed that the relationship between Heads of school's strategies and teachers' instructional performance was low in coordinating and teachers' instructional performance and students learning outcome. The major constraints included inadequate number of qualified teachers, excess workload for teachers, inadequate learning resources, lack of adequate and well-equipped offices for teachers and lack of conducive classrooms.

The study above did not give up the strategies to enhance coordinating and controlling strategies in regards to constraints identified which causes low coordinating relationships of Heads of schools and teacher instructional performance and students learning outcomes. Qualitative data were only used and one instrument of data collection which is inadequacy in terms of triangulations of data collected hence reliability of the findings is questionable. The current study used Cross sectional survey design where by both qualitative and quantitative approach were used and varieties of instruments to respondents were employed. Chemistry Quality Assurance Officer was included as opposed to previous study due to their roles. The current study was on Heads of school's strategies in enhancing Chemistry performance in National form four examinations in Hai District-Tanzania using multiple data collections instruments for collecting both types of data.

Mestry (2017) of University of Johannesburg in South Africa conducted a study to investigate how the principals perceived and experienced their functions as instructional leaders to improve learner performance. Descriptive research design was employed using open-ended questionnaires and personal interviews with a sample of eight school principals. The findings revealed that many school principals rejected claims that their primary function was to manage teaching and learning. Most educational leadership academics have studied the dynamics of successful school leadership that leads to effective schooling and high achievement of students. The study observed that the lack of effective leadership in schools lowers students' achievement because the absence of quality leadership often results in ill-adapted school organization.

The study did not specify strategies used by the principals to enhance performance though identified that lack of effective leadership strategies in schools leads to lower performance. Still there is a need to explore those effective leadership strategies that are lacking, hence a need to find out those effective strategies which matches with Chemistry subject in secondary schools' context. The previous study involved public primary and secondary schools which their contexts are different. Furthermore, the study could use more instruments for the purpose of triangulations of the data collected. Therefore, the current study examined Effectiveness of Strategies of Heads of schools in enhancing performance of Chemistry in secondary school in Hai district.

Boa (2014) examined the factors that influence high academic performance in private secondary schools in Kilimanjaro region. The qualitative approach was applied and Interviews, questionnaires, and documentary review were used for data collection. The study found that high performing secondary schools had enough qualified teachers, conducive teaching and learning environment, teaching insists on formative evaluations before accepting students in their schools and involvement of parents in students' progress.

The study by Boa considered only private schools which in some cases those strategies which are seem to be effective does not match with public schools. Furthermore, the study did not focus specifically for heads of schools. The current study concentrated on strategies used by heads of schools in enhancing Chemistry performance in form four national examinations both in private and public schools.

A study on Effect of Chemistry practical on students' performance in Chemistry in public secondary schools of Machakos and Nairobi counties in Kenya was done by Mwangi (2016). The study aimed at finding out the appropriate role played by Chemistry practical especially with continued decline in academic performance in Chemistry. Experimental design was used and data were collected using questionnaires and Achievement Tests done just before and immediately after exposure to the topic under investigation. The study findings showed that the use of Chemistry practical in teaching and learning of Chemistry improved performance. It was shown that there is a strong relationship existed between performance in Chemistry and frequency respectively of Chemistry practical used in the teaching and learning of Chemistry.

The study did not tell on availability and accessibility of the chemistry laboratories, equipments and chemicals and on weather teachers and students use them to conduct practical. The findings do not tell us if heads of schools have necessary skills in monitoring teaching and learning of chemistry practical. Furthermore, the experimental design used might be affected by external factor; there is a need to use both qualitative and quantitative under cross section survey design using both qualitative and quantitative approaches to obtain in-depth information. The current study examined heads of school's strategies in enhancing chemistry performance in Hai district.

The study by Abudu \& Gbadamosi (2014) to find out the relationship among teachers' attitude and student' academic achievement in secondary school chemistry. A quasi experimental design was adopted for the study. Chemistry students and all chemistry teachers from the selected secondary schools in Ijebu-Ode and Odogbolu Local Government Area in Nigeria were involved in the study. Teacher attitude towards chemistry teaching scale and Chemistry achievement test 
research instruments were used for data collection. Arising from the findings, it is implied that attitude of teachers teaching chemistry in senior secondary schools have significant effect on the achievement of students in chemistry.

The study was done on teachers' factors and did not deal with heads of school's factors in enhancing particularly the instructional leadership attitudes of heads of schools. Furthermore, the heads of schools were not involved in the study. The current study dealt with heads of school's factors in enhancing students Chemistry performance in ordinary secondary schools. The researcher believes at building strong foundations of chemistry for junior students so as to get more students in high school and tertiary educations specializing in Chemistry related courses.

Bamiro (2015) conducted a study on effects of guided discovery and think-pair-share strategies on Secondary School Students' Achievement in Chemistry on senior secondary school in Nigeria. The study employed a pretest, posttest, control group quasi-experimental design. Chemistry cognitive test and Chemistry achievement test was used in gathering data. It was found that students taught with guided discovery and think-pair-share strategies obtained significantly higher posttest mean scores than those in the lecture strategy. The study concluded that the use of guided discovery and thinkpair-share strategies had great potential for improving achievement in Chemistry.

The strategies are classroom strategies still requires support of heads of schools to the Chemistry teachers and students to enable the effective instructional by employing effective instructional strategies in teaching and learning Chemistry. Integration of varieties strategies is more effective as there is no single strategies can stand in its own. In order to fill the gap, the current study dealt with Effectiveness of heads of school's strategies to enhance Students Chemistry performance in form four National Examinations.

The study conducted in Bureti District in Kericho County, Kenya by Chepkorir, Cheptonui, \& Chemutai in 2014. The study examined the relationship between teacher-related factors and student's attitudes towards Chemistry subject in secondary schools in Kenya. The study highlighted issues on the teaching methods used by chemistry teachers. Further examined the teacher availability to attend to various needs of students on the subject, their use of teaching and learning resources in teaching, teachers' personal levels of skills and knowledge of the subject matter in Chemistry. The study explored also the impact of students' negative attitudes towards Chemistry on teachers' effectiveness. The research design used in the study was descriptive survey. Stratified random sampling and random sampling technique was used to select the study sample. The data collection instruments were questionnaires and document analysis. From the study findings, a number of indicators revealed that there are some factors influencing students' attitudes towards Chemistry. It was recommended that science teachers should encourage development of positive self-concept of ability among students.

The study dealt with teacher and student factors in enhancing Chemistry performance. There is a need to consider on strategies used by heads of schools in enhancing Chemistry performance since mandate are given to heads of schools to perform effectively the supervisory role on implementation of chemistry curriculum. The possible solutions included only lack of successful experiences in Chemistry and poor teaching but performance enhancing involves combination of many factors there is a need to explore more. Only questionnaire instrument used is inadequacy for triangulations of the findings.

A study by Tenaw (2013) in Nigeria investigated students' attitude and achievement in Chemistry as a correlate of teacher classroom management behaviors in Nigeria. Data were collected using direct-observation and questionnaires. The study revealed that, interest boosting; student involvement and varying instruction were found to have a strong, positive and significant correlation achievement in Chemistry.

Boosting student interest to the subject depends on other factors such as availability of teaching and learning resources to enhance Chemistry achievement. Furthermore, some strategies must be employed largely by the Heads of schools since they are given mandate by the government of making sure that chemistry performance is improved. To fill that gap the current study investigated Effectiveness of Head of School Strategies in enhancing Chemistry Performance.

\subsection{Summary of Literature Review and Knowledge Gap}

Various studies reviewed by the researcher were from Tanzania and outside Tanzania for instance Apolline (2014), Ayeni \& Akinfolarin (2014), Rviewu-mortty (2012), Boa (2012) and Mestry (2017). However, studies above inadequately investigated directly on heads of schools, strategies in enhancing Chemistry performance as they concentrated on general school administrative and instructional leadership. Other studies by Bamiro (2015), Chepkorir, Cheptonui \& Chemutai (2014), Mwangi (2016), Abudu \& Gbadamosi (2014) and Tenaw (2013). These studies concentrated in teachers and student factors and little has been done in heads of schools, factors in enhancing Chemistry performance. Furthermore there is no evidence of the study which has been done to address on the Effectiveness of Heads of schools strategies to enhance Chemistry Performance in Hai district-Tanzania. Therefore the current study examined effectiveness of Heads of schools strategies in enhancing students Chemistry Performance in Form four national Examinations in Hai district.

\section{Design and Methodology}

\subsection{Design}

With regard to this study Cross sectional survey and phenomenology research designs were employed under quantitative and qualitative approaches respectively. 


\subsection{Target Population}

The study involved 44 secondary schools 29 public and 15 private schools in Hai district. 44 Heads of schools, 65 Chemistry teachers and 1156 form four students, 04 Chemistry Quality Assurance Officers and 01 DSEO making a total of 1270 target population.

\subsection{Description of the Sample and Sampling Procedures}

The study constituted sample size of 09 secondary schools, 06 public and 03 private secondary schools, one DSEO and one Chemistry Quality Assurance Officer. All 09 Heads of schools of the sampled schools automatically were selected to participate in the study, 18 Chemistry teacher and 90 form four Chemistry students were sampled to participate in the study making a total sample of 119 respondents.

\subsection{Sampling Procedures}

The sampling of schools was done by using probability procedures. Secondary schools were sampled using stratified sampling to obtain two strata, public and private schools. Form Four Chemistry students were sampled by stratified sampling to obtain male and female respondents. 05 males and 05 female students from each school participated in the study making total of 90 students. Chemistry teachers were conveniently selected to obtain two teachers from each school making a total of 18 teachers. All 09 Heads of schools of the sampled school were automatically included in the study. The DSEO was automatically involved in the study. One Chemistry Quality Assurance Officer was purposively selected to participate in the study.

\begin{tabular}{|c|c|c|c|c|}
\hline $\begin{array}{c}\text { Participants } \\
\text { Technique }\end{array}$ & Population & Sample & \% & Sampling \\
\hline Heads of Schools & 4 & 09 & 26 & Automatic \\
Chemistry teachers & 65 & 18 & & Convenient \\
Chemistry students & 1156 & 90 & 21 & Stratified \&Simple random \\
Quality Assurance Officers & 04 & 01 & 25 & purposive \\
DSEO & 01 & 01 & 100 & Automatic \\
\hline Total & 1270 & 119 & 22 & \\
\hline
\end{tabular}

Table 2: Sampling Frame

Field Data, 2018

\subsection{Description of Data Collection Instruments.}

The study employed Questionnaires, interview guide and Documentary analysis guide instruments to collect data from the participants.

\subsubsection{Questionnaires}

The questionnaires containing both open ended and closed ended items were administered to Heads of schools, teachers and students.

\subsubsection{Interview Guide}

Interview guide were used to collect data DSEO and quality Assurance Officer.

\subsubsection{Documentary Analysis Guide}

This instrument was used to obtain secondary data. All documents relating to strategies and Chemistry results were reviewed.

\subsection{Validity of Research Instruments}

To ensure validity the researcher reviewed the instruments under the guidance of the esteemed education experts at MWECAU. Furthermore, the researcher conducted a pilot study to make sure that data collected provided valid information. Questionnaires were tried out on a small sample which was not part of the study within the study area. The results collected indicated that the data collection instruments were valid after the researcher made corrections before conducting the main study.

\subsection{Pilot Testing}

The questionnaires were administered to10 Form Four Chemistry students, 6 Chemistry teachers and 3 Heads of schools which enabled the researcher to familiarize with problems which might be encountered in the field and improving the instruments before conducting the main study.

\subsection{Reliability of Research Instruments}

In this study the researcher used split-half technique to establish the internal consistency of the instruments. This involved splitting the statement (items) into two halves (odd and even) items. In this study all odd numbered items and even numbered items subsets were treated separately and scored accordingly. The two subsets were correlated using Pearson's product moment correlation coefficient in the SPSS. The reliability calculated was 0.849 . 


\subsection{Description of Data collection Procedures}

The researcher obtained an introduction letter from the Directorate of Postgraduate Studies of MWECAU. The letter assisted in seeking a research permit from the DSEO in Hai District and to have access to a study area. In the field the researcher administered the research instruments questionnaires for students, Chemistry teachers and Heads of schools and interview guide for DSEO and Chemistry Quality Assurance Officer in person after visiting the researcher actual visited each sampled schools with questionnaires and arranging to meet with respondents, administering questionnaires to them and collecting them after a specified time, in accordance with the agreed date and time. For document analysis guide the researcher asked for the permission from the Heads of schools and DSEO to have access to the required records at a convenient time the reviewed documents which included schemes of work, lesson plans and Chemistry subject logbooks and national form four chemistry performance in order to collect secondary data.

\subsection{Data Analysis Procedures}

The study used both quantitative and qualitative techniques in analyzing data. The quantitative data were analyzed and presented through frequencies, mean, percentages and tables. Statistical Package for Social Sciences (SPSS) was directly employed for analyzing quantitative data. Qualitative data particularly from interview guides were transcribed, coded and presented in narrations form. Hypothesis was tested using Pearson correlation coefficient at significance level of 0.05 .

\section{Presentation and Discussion of the Findings}

\subsection{Discussion of Findings According to the Research Question One}

Research Questions one sought to find out the effectiveness of strategies used by heads of schools in enhancing chemistry performance in form four national examinations in Hai district.

\subsubsection{Students Responses.}

Questionnaires were used to collect information from form four students. Findings are shown in table below

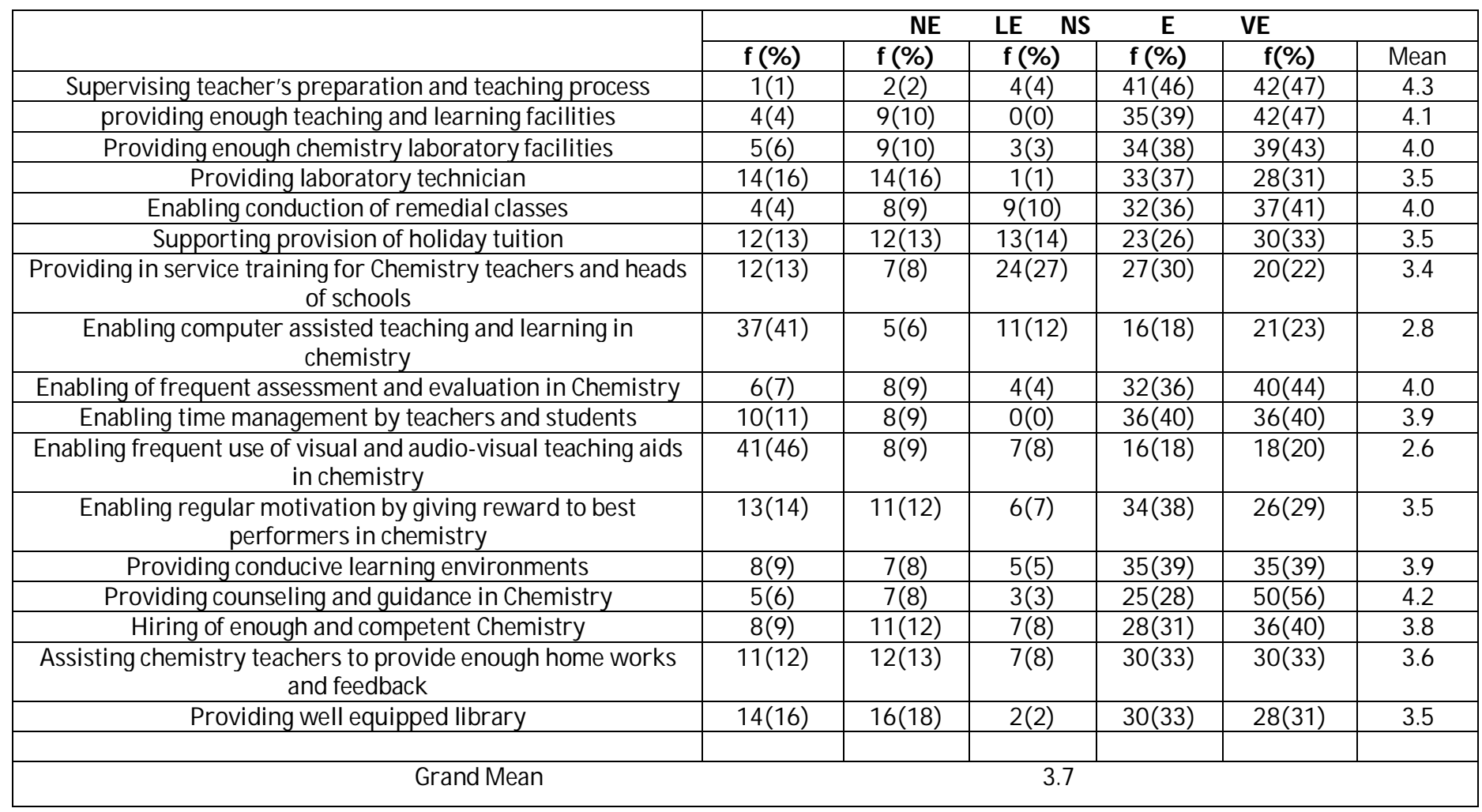

Table 3: Students Responses on the Effectiveness of Strategies Used by Heads of Schools to Enhance Chemistry Performance $(\mathrm{N}=90)$.

Key: NE=Not Effective, LE=Less Effective, N=Neutral, E=Effective, VE=Very Effective Source: Field Data 2018

The findings in Table 10 illustrates the grand mean score of 3.7 which indicates that majority students indicated the effectiveness of various strategies implemented by the heads of schools in enhancing chemistry performance as moderately effective. In other hand the following individual strategies were identified to be very effective; supervising teacher's preparation and teaching process $42(47 \%)$ (4.3), hiring of enough and competent Chemistry teachers 36(40\%) (3.8), providing counseling and guidance 50(56\%) (4.2), enabling of frequent assessment and evaluation 40(44\%) (4.0), providing enough teaching and learning facilities $42(47 \%)(4.1)$, providing enough chemistry laboratory facilities 39(43\%) (4.0) and enabling conduction of remedial classes 37(41\%) (4.0). It implies that if head of schools supports 
students and Chemistry teachers to use the above strategies more success of student's performance of Chemistry will be enhanced. This finding is in agreement with a study done by Boa (2014) in Kilimanjaro which showed that for effective teaching and learning processes to take place, supervision is considered important aspect that make the actions of preventing misuse of human and material resources, wastage of time, and the issue of teaching profession incompliance, promote quality of teaching and increase of teachers' creativity. It also helps the improvement of teaching and learning process.

Furthermore students indicated the following strategies used by heads of schools as moderately effective strategies as their frequencies and mean shown beside the statements below: Assisting chemistry teachers to provide enough home works and feedback 30(33\%) (3.6), providing laboratory technician 33(37\%) (3.5) and providing conducive learning environments 35(39\%) (3.9).Supporting provision of holiday tuition 23(26\%) (3.5), enabling regular reward to best performers in chemistry 34(38\%) (3.5) and providing well equipped library 30(33\%) (3.5). Mwangi (2016) argued that students who are more academically confident and engaged tend to have more supportive relationships with teachers.

Finally, students rated the following strategies ineffectively used by heads of schools in enhancing chemistry performance since the mean score was below 3.5, Providing in service training for Chemistry teachers mean (3.4), enabling computer assisted teaching and learning in Chemistry (2.8) enabling frequent use of visual and audio-visual teaching aids in chemistry (2.6). According to research by Kanno (2007) observed that when teachers attend useful and practical seminars, conferences and workshops they raise their qualifications. It is therefore important that teachers and heads of schools to upgrade their skills in enhancing chemistry teaching and learning process hence higher performance in Chemistry.

\subsubsection{Chemistry Teachers Responses.}

The study sought to find out Chemistry teachers' opinion on the effectiveness of heads of school's strategies in enhancing chemistry performance. Questionnaires were used to collect information from chemistry teachers. The findings are presented in the Table 4.9.

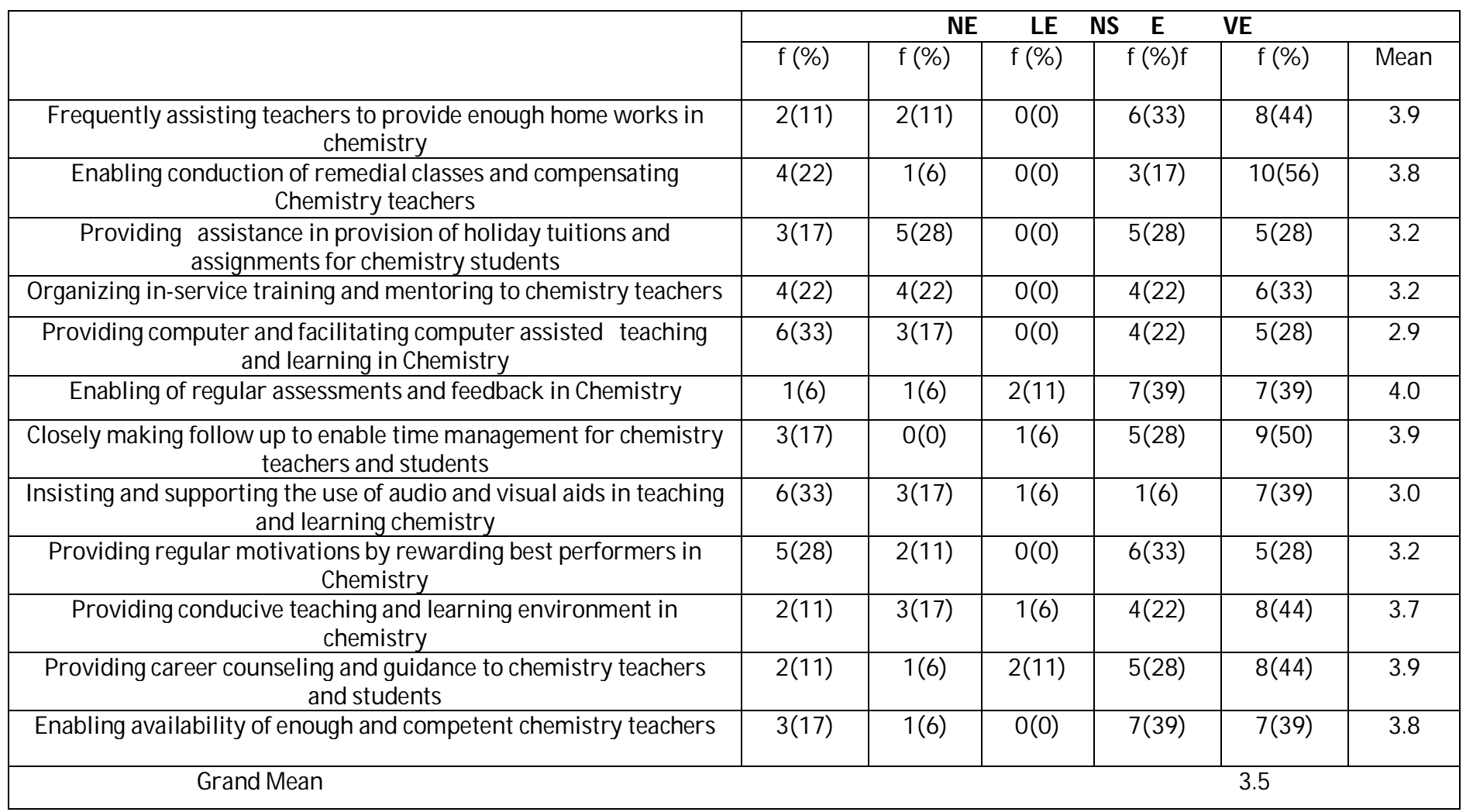

Table 4: Chemistry Teachers Responses on the Effectiveness of Strategies Used ( $\mathrm{N}=18$ ).

Key: NE=Not Effective, LE=Less Effective, N=Neutral, E=Effective, VE=Very Effective Source: Field Data 2018

As shown in Table 4.9 chemistry teachers were asked to indicate their views on the effectiveness of strategies used by heads of schools in enhancing chemistry performance in form four national examinations. The overall means scores average was 3.5 indicating that majority of teachers rated very effective on frequently assisting teachers to provide many homework in chemistry $8(44 \%)$ (3.9), enabling conduction of remedial classes and compensating Chemistry teachers 10(56\%) (3.8), closely making follow up to enable time management for chemistry teachers and students $9(50 \%)$ (3.9), providing conducive teaching and learning environment in chemistry 8(44\%) (3.7) and providing career counseling and guidance to chemistry teachers and students $8(44 \%)(3.9)$, enabling of regular assessments and feedback in Chemistry 7(39) (4.0) and enabling availability of enough and competent chemistry teachers 7(39\%) (3.8). the findings implies that heads of schools strategies to enhance chemistry performance in form four national examinations are very useful by the 
teachers in the process of teaching and learning for instance Musungu, Achoka, Kasandi, \& Wamochamasinde (2008) found that guiding and counseling played a very significant role in motivational strategies used by head teachers to improve the academic performance. Rewards and discipline were also found to be very important motivational strategies. Hence the head of schools are expected to provide the right motivation and stimulation for teachers so as to enhance high academic performance which have numerous forms of assessing, monitoring and evaluation of teacher activities which further propels them to work hard and continuously improve chemistry performance. Less effective strategies according to chemistry teachers were computer assisted teaching and learning in Chemistry 5(28\%) (2.9), insisting and supporting the use of audio and visual aids in teaching and learning chemistry $7(39 \%)(3.0)$, providing regular motivations by rewarding best performers in Chemistry 5(28\%) (3.2), providing assistance in provision of holiday tuitions and assignments 5(28\%) (3.2), organizing in-service training and mentoring to chemistry teachers $6(33 \%)(3.2)$. Basing on the findings from chemistry teachers it implies that chemistry teachers recommended those strategies as ineffective used in enhancing chemistry performance in their schools due to some challenges which faces the heads of schools in implementing effective strategies such as absence of on line libraries for downloading various chemistry materials to complements with those available in schools. According to findings by Ronald \& Frankwell (2014) revealed that the school library information resources were not satisfactory to users because mostly used information resources in secondary schools were physical books.

\subsubsection{Heads of School Responses ( $N=09$ )}

The study sought to find the effectiveness of heads of school's strategies in enhancing chemistry performance. Questionnaires were used to collect information from heads of schools. The findings are presented in Table 4.10.

\begin{tabular}{|c|c|c|c|c|c|c|}
\hline & $\mathbf{N E}$ & $\mathbf{L E}$ & $\mathbf{N S}$ & $\mathbf{E}$ & $\mathbf{V E}$ & Mean \\
\cline { 2 - 5 } & $\mathrm{f}(\%)$ & $\mathrm{f}(\%)$ & $\mathrm{f}(\%)$ & $\mathrm{f}(\%)$ & $\mathrm{f}(\%)$ & \\
\hline $\begin{array}{c}\text { Effective supervision of teacher preparation and } \\
\text { teaching process }\end{array}$ & $0(0)$ & $0(0)$ & $0(0)$ & $6(67)$ & $3(33)$ & 4.3 \\
\hline $\begin{array}{c}\text { Providing enough Chemistry teaching and learning } \\
\text { resources }\end{array}$ & $0(0)$ & $0(0)$ & $0(0)$ & $4(44)$ & $5(56)$ & 4.6 \\
\hline $\begin{array}{c}\text { Providing enough Chemistry facilities } \\
\text { Providing laboratory technician }\end{array}$ & $0(0)$ & $0(0)$ & $0(0)$ & $6(67)$ & $3(33)$ & 4.3 \\
\hline $\begin{array}{c}\text { Enabling conduction of effective remedial classes } \\
\text { for Chemistry }\end{array}$ & $1(11)$ & $2(22)$ & $0(0)$ & $6(67)$ & $0(0)$ & 3.2 \\
\hline $\begin{array}{c}\text { Ensuring provision of holiday home package for } \\
\text { Chemistry }\end{array}$ & $0(0)$ & $0(0)$ & $0(0)$ & $9(100)$ & $0(0)$ & 5.0 \\
\hline $\begin{array}{c}\text { Ensuring in-service training and mentoring of } \\
\text { chemistry teachers }\end{array}$ & $2(22)$ & $4(44)$ & $0(0)$ & $2(22)$ & $1(12)$ & 2.6 \\
\hline $\begin{array}{c}\text { Enabling Computer assisted teaching and learning } \\
\text { in Chemistry }\end{array}$ & $3(33)$ & $5(56)$ & $0(0)$ & $1(11)$ & $0(0)$ & 1.9 \\
\hline $\begin{array}{c}\text { Enabling effective students' assessments and } \\
\text { evaluation in Chemistry }\end{array}$ & $0(0)$ & $2(22)$ & $0(0)$ & $7(78)$ & $0(0)$ & 3.8 \\
\hline $\begin{array}{c}\text { Enabling effective time management by chemistry } \\
\text { teachers and students }\end{array}$ & $1(11)$ & $0(0)$ & $2(22)$ & $5(56)$ & $1(11)$ & 3.8 \\
\hline $\begin{array}{c}\text { Enabling classroom use of audio and visual } \\
\text { teaching aids in Chemistry }\end{array}$ & $2(22)$ & $5(56)$ & $0(0)$ & $2(22)$ & $0(0)$ & 2.1 \\
\hline $\begin{array}{c}\text { Provision of regular motivation and rewards for } \\
\text { best performers both teachers and students in } \\
\text { Chemistry }\end{array}$ & $1(11)$ & $0(0)$ & $2(22)$ & $5(56)$ & $1(11)$ & 3.6 \\
\hline Provision of Chemistry conducive environment & $1(11)$ & $1(11)$ & $0(0)$ & $7(78)$ & $0(0)$ & 3.4 \\
\hline $\begin{array}{c}\text { Provision of guidance and counseling for both } \\
\text { Chemistry teachers and students }\end{array}$ & $0(0)$ & $1(11)$ & $0(0)$ & $7(78)$ & $1(11)$ & 3.9 \\
\hline Hiring of enough competent Chemistry teacher & $0(0)$ & $2(22)$ & $0(0)$ & $7(78)$ & $0(0)$ & 3.6 \\
\hline $\begin{array}{c}\text { Enabling provision of enough home works and } \\
\text { assignment in Chemistry }\end{array}$ & $0(0)$ & $0(0)$ & $0(0)$ & $8(89)$ & $1(11)$ & 4.1 \\
\hline $\begin{array}{c}\text { Provision of library books for chemistry } \\
\text { Grand mean }\end{array}$ & $0(0)$ & $0(0)$ & $0(0)$ & $6(67)$ & $3(33)$ & 4.3 \\
\hline \begin{tabular}{c} 
Table 5: Gads \\
\hline
\end{tabular} & & & & & 3.4 \\
\hline
\end{tabular}

Table 5: Heads of School's Responses on Effectiveness of Strategies Used by Heads of Schools ( $\mathrm{N}=9$ )

Key: Ne=Not Effective, Le=Less Effective, N=Neutral, E=Effective, Ve=Very Effective

Source: Field Data 2018

Table 4.10 illustrates the effectiveness of strategies used by heads of schools in enhancing chemistry performance. Majority of heads of schools 6(67\%) (4.3) rated the following as effective strategies: Ssupervision of teacher preparation and teaching process, 4(44\%) (4.6) providing enough Chemistry teaching and learning resources 6(67\%) (4.3) providing enough Chemistry facilities, ensuring provision of holiday home package for Chemistry 9(100) (5.0), enabling provision of enough home works and assignment in Chemistry 8(89\%) (4.1) and Provision of library books for chemistry 6(67\%) (4.3\%).This implies that heads of schools ensures teacher preparedness in teaching of the subject matter through effective supervision of teachers and students in the teaching and learning process. The findings from interview with zonal 
chemistry quality assurance officer showed that the teaching and learning of chemistry is still using content based pedagogy in most schools and that chemistry teachers and heads of schools were advised accordingly to use competence based pedagogy this can be evidenced from the findings for instance head of schools mean in enabling classroom use of audio and visual teaching aids in Chemistry strategy was (2.1), enabling Computer assisted teaching and learning in Chemistry (1.9), Providing laboratory technician (1.9), Provision of Chemistry conducive environment (3.4), Provision of regular motivation and rewards for best performers both teachers and students in Chemistry (3.6), Hiring of enough competent Chemistry teacher (3.6).This means that heads of schools find it as not effectively used in their schools this finding is in congruence with study by Mwangi (2016) asserted that successful teaching and learning of Chemistry depends partly on methods whose activities target most learning senses. This may imply that there is need for teachers to vary the teaching technique in their day to day teaching activity. Apart from the most commonly applied lecture method approach there is need to employ other teaching methodology such as class demonstrations, practical's and field excursions which are more students involving. The findings further implies that heads of schools ensures effective assessment and evaluation of teacher in teaching process. According to quality assurance officer Strategies used in high performing schools in chemistry were hard-working of chemistry teachers, good school leadership, availability of teaching and learning of facilities and good school infrastructures.

\subsection{Discussion of Findings According to Research Questions Two.}

The research questions two intended to find out how teachers and students use strategies of heads of school in enhancing students' chemistry performance in national form four examinations in Hai district. The Ministry of Education and Vocational Training (MoEVT, 2011) through the secondary education development programme II document, stipulated that, among other duties, heads of secondary schools would be responsible for supervising the teaching programme, ensuring high quality teaching and learning, conducive teaching and learning environment. Therefore, every head of school is accountable for the development of school academically; he/ she must lay down strategies to ensure that the school achieves good academic progress. The researcher attempted to know if teachers and students are supported and use strategies of heads of school to enhance performance of Chemistry in national form four examinations in Hai district.

\subsubsection{Students' Responses}

The researcher asked students to indicate the teachers and students use of strategies of head of school in enhancing students' chemistry performance in national examinations in Hai District. Eighteen items were rated with five Likert scales and five options; 1. Strongly disagree, 2. Disagree, 3. Undecided 4. Agree and 5. Strongly disagree. The items were administered to find out if the students and teachers use heads of school strategies in Hai District. Table 4.11 summarizes the findings.

\begin{tabular}{|c|c|c|c|c|c|c|}
\hline & \multicolumn{2}{|c}{ SD } & \multicolumn{3}{c|}{ U A } & SA \\
\cline { 2 - 7 } & $\mathrm{f} \%$ & $\mathrm{f} \%$ & $\mathrm{f} \%$ & $\mathrm{f} \%$ & $\mathrm{f} \%$ & Mean \\
\hline Frequent demonstrations & $2(2)$ & $4(4)$ & $1(1)$ & $52(58)$ & $31(34)$ & 4.2 \\
\hline Conducting frequent experiments in chemistry & $3(3)$ & $4(4)$ & $5(6)$ & $45(50)$ & $33(37)$ & 4.1 \\
\hline Use of cooperative learning frequently & $3(3)$ & $7(8)$ & $7(8)$ & $37(41)$ & $36(40)$ & 4.1 \\
\hline Doing projects in form three and four & $18(20)$ & $13(14)$ & $7(8)$ & $23(26)$ & $29(32)$ & 3.4 \\
\hline Using computer assisted teaching and learning in chemistry & $39(43)$ & $16(18)$ & $6(7)$ & $20(22)$ & $9(10)$ & 2.4 \\
\hline Use of think pair and share strategies & $7(8)$ & $3(3)$ & $17(19)$ & $34(38)$ & $29(32)$ & 3.8 \\
\hline use of guided discovery strategies & $13(14)$ & $17(19)$ & $13(14)$ & $33(37)$ & $14(16)$ & 3.2 \\
\hline Frequent use of audio-visual aids & $32(36)$ & $17(19)$ & $11(12)$ & $19(21)$ & $11(12)$ & 2.6 \\
\hline Frequent study tours to learn application of chemistry in \\
industries & $30(33)$ & $18(20)$ & $7(8)$ & $13(14)$ & $22(24)$ & 2.8 \\
\hline Inviting guest speakers in chemistry related fields experts & $19(21)$ & $15(17)$ & $9(10)$ & $31(34)$ & $16(18)$ & 3.1 \\
\hline Frequent provision of career Counseling of chemistry related & $7(8)$ & $6(7)$ & $14(16)$ & $31(34)$ & $32(36)$ & 3.8 \\
\hline courses & & & & & & \\
\hline Uof jigsaw teaching strategies & $7(8)$ & $8(9)$ & $13(14)$ & $30(33)$ & $32(36)$ & 3.8 \\
\hline Frequent use of problem-solving techniques & $5(6)$ & $5(6)$ & $6(7)$ & $31(34)$ & $43(48)$ & 4.1 \\
\hline Frequent use of group discussion strategies & $4(4)$ & $4(4)$ & $3(3)$ & $31(34)$ & $48(53)$ & 4.3 \\
\hline Frequent use of student's class presentation & $1(1)$ & $7(8)$ & $5(6)$ & $41(46)$ & $36(40)$ & 4.2 \\
\hline Use of peer tutoring strategies & $7(8)$ & $9(10)$ & $11(12)$ & $38(42)$ & $25(28)$ & 3.7 \\
\hline Use of frequent lecturing & $8(9)$ & $9(10)$ & $14(16)$ & $35(39)$ & $24(27)$ & 3.6 \\
\hline Coping notes strategies & $4(4)$ & $5(6)$ & $2(2)$ & $33(37)$ & $46(51)$ & 4.2 \\
\hline Grand mean & \multicolumn{3}{|c|}{3.4} & & \\
\hline
\end{tabular}

Table 6: Students Response on How Students and Chemistry Teachers Apply Strategies Used by Heads of Schools (N=90)

1. SD=Strongly Disagree, 2. D=Disagree, 3. U=Undecided 4. A=Agree And 5. SA=Strongly Agree Source: Field Data 2018

Results in table 4.11. Shows that majority of the students moderately agree that they use strategies of heads of school in enhancing chemistry performance since the overall mean is 3.4 which relies between undecided and agree in the Likert scale. The following classroom strategies, their frequency and mean in brackets got high score showing that students agree that those strategies are used by students and Chemistry teachers in enhancing Chemistry performance in their schools: frequent use of group discussion strategies 48(53\%)(4.3) conducting frequent demonstrations 52(58\%) 
(4.2) conducting frequent experiments in chemistry 45(50\%) (4.1), use of cooperative learning frequently 37(41\%) (4.1), frequent use of problem solving techniques strategies 43(48\%) (4.1), frequent use of students class presentation 41(46\%) (4.2), indicating that the teachers and students use head of school strategies to enhance Chemistry performance. The methods used above are good for use to enhance chemistry performance for instance Oxford (2003) reported that discussion has advantage of giving introverts opportunity to participate equally with extroverts, the findings does not support the current research findings which found that attendance to laboratory and library were occasionally done in secondary school chemistry and suggested the schools to employ competence based teaching strategies since most chemistry teachers still uses content based approach in teaching. Furthermore, the study found some challenges which might be hindering the use of those strategies which includes shortages of chemistry teachers and absence of chemistry laboratory apparatus and chemicals.

The following strategies had low mean score: Doing projects in form three and four 29(32\%) (3.4), using computer assisted teaching and learning in chemistry 9(10\%) (2.8), frequent use of audio visual aids, frequent study tours to learn application of chemistry in industries, inviting guest speakers in chemistry related fields experts16(18\%) (3.1), frequent provision of career counseling of chemistry related courses $32(36 \%)(3.80)$, use of guided discovery strategies 33(37\% (3.2), use of jigsaw teaching strategies 32(36\%) (3.8). Use of think pair and share strategies 34(38\%) (3.8), use of peer tutoring strategies 38(42\%) (3.7) and use of frequent lecturing 24(27\%) (3.6). It implies that most of the strategies used by heads of schools are not well used by students and chemistry teachers hence hindering chemistry performance since use of varieties of effective instructional strategies favors students to actively participate in their learning and enhances chemistry performance. Therefore, it seems that the heads of schools are not effectively supervising the student and chemistry teachers in regards of the chemistry curriculum delivery. The findings are in agreement with the study done by Mugambi (2015) in Kenya which revealed that there is an association between the school's performance and heads of school instructional management practices.

\subsubsection{Chemistry Teachers' Responses}

The study sought to figure out how the teachers and students use the strategies used by heads of schools in enhancing students' chemistry performance in national examinations in Hai District. Chemistry teachers play a crucial role to ensure strategies of heads of school are put into the practices, so the heads of school should support their strategies in order to achieve the intended goals. The researcher needed the teachers to indicate their extent of agreement or disagreement, where by seventeen items were rated with Likert scale in five option 1. Strongly disagree, 2. Disagree, 3. Undecided 4. Agree and 5 strongly agree. The findings are summarized in the table 4.12. below.

\begin{tabular}{|c|c|c|c|c|c|c|}
\hline & \multicolumn{2}{|c}{ SD D } & U & SA \\
\cline { 2 - 6 } & $\mathrm{f}(\%)$ & $\mathrm{f}(\%)$ & $\mathrm{f}(\%)$ & $\mathrm{f}(\%)$ & $\mathrm{f}(\%)$ & Mean \\
\hline Frequent conducting demonstrations in laboratory & $1(6)$ & $0(0)$ & $2(11)$ & $8(44)$ & $7(39)$ & 4.1 \\
\hline Frequent conducting laboratory experiments in chemistry & $0(0)$ & $1(6)$ & $0(0)$ & $7(39)$ & $10(56)$ & 4.4 \\
\hline $\begin{array}{c}\text { Frequent use of cooperative instructional teaching and learning in } \\
\text { chemistry lessons }\end{array}$ & $0(0)$ & $0(0)$ & $3(17)$ & $4(22)$ & $11(61)$ & 4.4 \\
\hline Frequent conducting project-based learning in chemistry & $2(11)$ & $2(11)$ & $0(0)$ & $7(39)$ & $7(39)$ & 3.8 \\
\hline Frequent use of computer assisted teaching and learning in chemistry & $5(28)$ & $1(6)$ & $3(17)$ & $7(39)$ & $2(11)$ & 3.0 \\
\hline $\begin{array}{c}\text { Frequent use of Think pair and share strategies in teaching and } \\
\text { learning chemistry }\end{array}$ & $0(0)$ & $2(11)$ & $3(17)$ & $6(33)$ & $7(39)$ & 4.0 \\
\hline Frequent use of guided discovery learning in chemistry & $0(0)$ & $3(17)$ & $2(11)$ & $8(44)$ & $5(28)$ & 3.8 \\
\hline Frequent use of audio and visual teaching aids in chemistry & $7(39)$ & $1(6)$ & $2(11)$ & $4(22)$ & $4(22)$ & 2.8 \\
\hline $\begin{array}{c}\text { Conducting study tour to chemical industries to learn chemistry } \\
\text { application in real life }\end{array}$ & $3(17)$ & $2(11)$ & $0(0)$ & $7(39)$ & $6(33)$ & 3.6 \\
\hline $\begin{array}{c}\text { Invitation of chemistry related field experts such as Pharmacists and } \\
\text { doctors to teach and encourage chemistry students }\end{array}$ & $0(0)$ & $3(17)$ & $4(22)$ & $7(39)$ & $4(22)$ & 3.7 \\
\hline Frequent provision of career counseling in chemistry related fields & $1(6)$ & $5(28)$ & $1(6)$ & $5(28)$ & $6(33)$ & 3.6 \\
\hline Frequent use of Jigsaw strategies in teaching chemistry & $1(6)$ & $1(6)$ & $3(17)$ & $6(33)$ & $7(39)$ & 3.9 \\
\hline $\begin{array}{c}\text { Frequent use of problem-solving strategies in teaching and learning } \\
\text { chemistry }\end{array}$ & $0(0)$ & $1(6)$ & $0(0)$ & $11(61)$ & $6(33)$ & 4.2 \\
\hline Frequent use of students group discussion & $0(0)$ & $1(6)$ & $0(0)$ & $11(61)$ & $6(33)$ & 4.2 \\
\hline Frequent use of student's discussion and presentation & $1(6)$ & $2(11)$ & $3(13)$ & $7(39)$ & $5(28)$ & 3.7 \\
\hline Frequent use of lecture methods in chemistry & $2(2)$ & $4(22)$ & $2(11)$ & $4(22)$ & $6(33)$ & 3.4 \\
\hline $\begin{array}{c}\text { Encouraging notes making skills and not notes taking for Chemistry } \\
\text { students }\end{array}$ & $3(17)$ & $1(6)$ & $3(17)$ & $4(22)$ & $7(39)$ & 3.6 \\
\hline Grand mean & & & & 3.8 & & \\
\hline
\end{tabular}

Table 7: Chemistry Teachers' Response on the Extent to Which Teachers and Students Use of Strategies ( $\mathrm{N}=18$ )

1. Strongly Disagree, 2. Disagree, 3. Undecided 4 Agree and 5. Strongly Agree Source: Field Data 2018

From Table 4.12 it shows that the overall mean of chemistry teachers was 3.8, which shows that they moderately agree strategies used by heads of schools in enhancing chemistry performance as follows: $11(61 \%)(4.4)$ of teachers strong agreed on that they frequent use of cooperative instructional teaching and learning in chemistry lessons as the strategies to influence students chemistry performance, 11(61\%) (4.2) frequent uses students discussion, 10(56\%) (4.4) of the teachers strong agreed that they use frequent conducting laboratory experiments in chemistry as the strategies they 
use to improve students chemistry performance, 7(39\%) (4.0) frequent uses of Think pair and share strategies in teaching and learning chemistry. Other responses were 11(61\%) (4.2) agreed on frequent use of problem-solving strategies in teaching and learning chemistry, 6(33\%) (4.2) use group discussion strategies. Furthermore $8(44 \%)(4.1)$ agreed on frequent conducting demonstrations in laboratory, 8(44\%) (3.8) frequent use guided discovery learning in chemistry. The following strategies were rated below mean of 4: This implies that the strategies were not used significantly to improve student chemistry performance Jigsaw strategies 7(39\%) (3.9) in teaching chemistry, 7(39\%) (3.6) uses encouraging notes making skills and not notes taking for Chemistry students as the strategies teachers they use as proposed by heads of school to improve students Chemistry performance in national examinations 7(39\%) (3.8) of the teachers said they frequent conduct project based learning in chemistry, 7 (39\%) (3.0) of the teachers agreed frequent use of computer assisted teaching and learning in chemistry, 6(33\%) (3.6) Conducting study tour to industries to learn chemistry application in real life, 7(39\%) (3.7) invitation of chemistry related field experts such as pharmacists and doctors to encourage chemistry students and 7(39\%) (3.7) frequent use of student discussion and presentation, such as frequent use of computer assisted teaching and learning in chemistry. (Mean 3.0), Frequent use of audio and visual teaching aids in chemistry mean 2.8, Frequent use of lecture methods in chemistry mean (3.4) as the strategies used by teachers to improve student's chemistry performance in national examination. The grand mean was (3.8) this means that teachers agree moderately that use different strategies introduced by the heads of schools to improve student chemistry performance. The findings are in congruence with Chemistry performance in the district since average performance in chemistry according to the responses by various respondents was rated to be average. This is against the national expectation that require performance in Chemistry to be higher.

\subsubsection{Heads of School Responses}

The researcher wanted heads of schools to show if the Chemistry teachers and students use strategies suggested by heads of schools in enhancing student performance. The heads of school should support students and teachers to improve students' performance in national examinations. Questionnaires were used to collect the required information. About 17 items were administered to the heads of school in Likert scale rate in five options, 1. Strongly disagree, 2. Disagree, 3. Undecided 4. Agree and 5 strongly agree. The data are summarized in the table below:

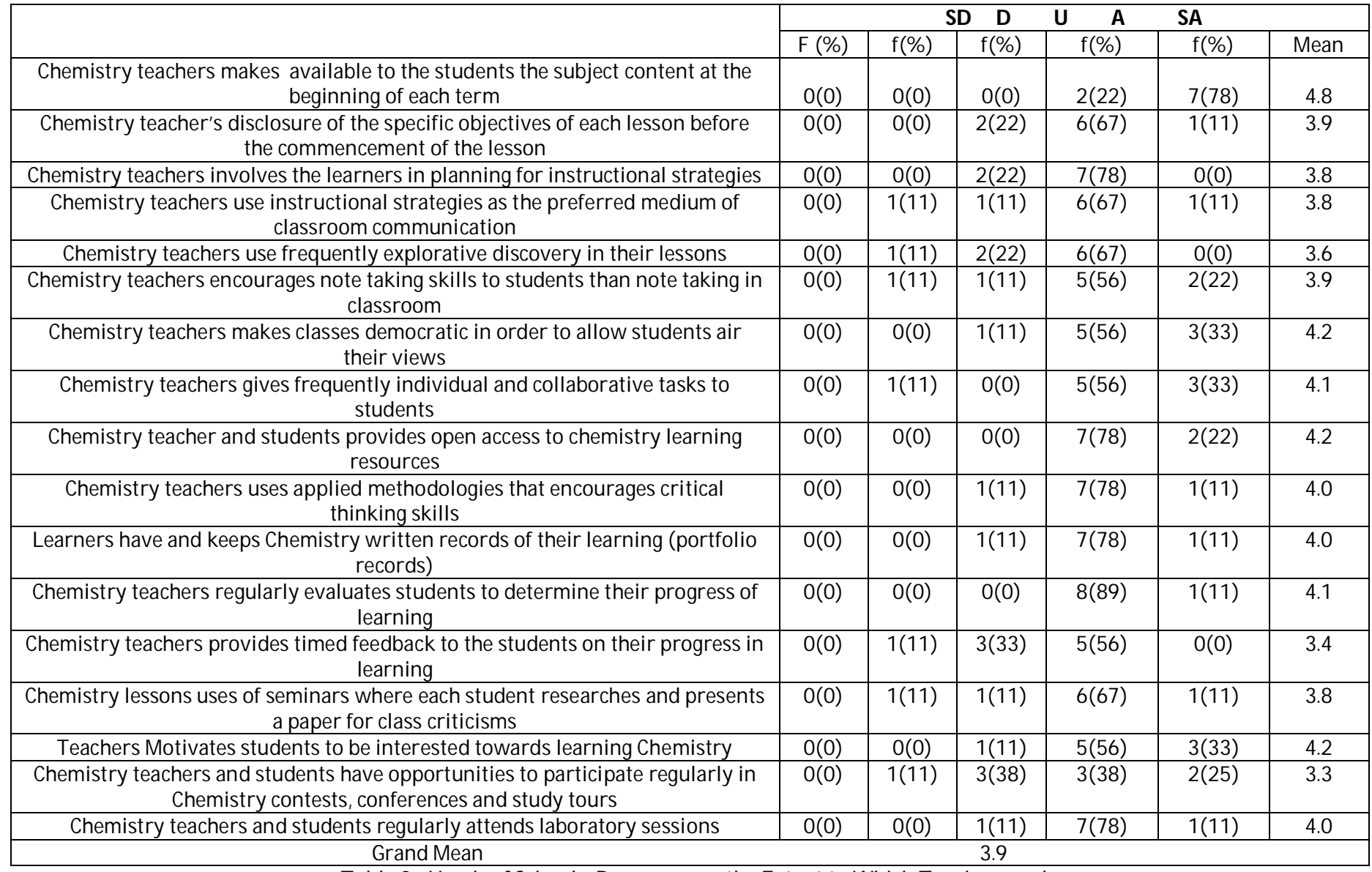

Table 8: Heads of School's Responses on the Extent to Which Teachers and

Students Use Strategies Used by Heads of Schools $(\mathrm{N}=9)$

Key: SD=Strongly Disagree, D=Disagree, U=Undecided, A=Agree, SA=Strongly Disagree

Source: Field Data 2018

Table 4.13. It was revealed that the overall mean was 3.9 showing that heads of schools agree that chemistry teachers and student uses heads of school strategies in enhancing performance in chemistry as the means scores average approaches 4. Frequencies and mean Scores for each statement was as follows; 7(78\%)(4.8) agreed on chemistry teachers makes available to the students the subject content at the beginning of each term as the strategies of students and teachers to enhance students chemistry performance, $7(78 \%)(4.2)$ chemistry teacher and students provides open access to 
chemistry learning resources, $7(78 \%)$ (4.0) Chemistry teachers use methodologies that encourage critical thinking skills, 7(78\%) (4.0) learners have and keeps Chemistry written records of their learning (portfolio records), 8(89\%) (4.1) chemistry teachers regularly evaluate students to determine their progress of learning, 7(78\%) (4.0) chemistry teachers and students regularly attend laboratory sessions, 5(56\%)(4.2) chemistry teachers makes classes democratic in order to allow students air their views, 5(56\%)(4.1) chemistry teachers gives frequently individual and collaborative tasks to students, 5(56\%)(3.4) chemistry teachers provides timed feedback to the students on their progress in learning and $5(56 \%)(4.2)$ motivates students to be interested towards learning Chemistry as the strategies teachers and students use to improve students chemistry performance in national form four examinations. The average mean of the study was ( $M=3.9)$ this means that most of the heads of school indicated that teachers and students use strategies of heads of school to enhance student's chemistry performance.

However the following strategies were not effectively used as the mean scores is less than 4 as follows: chemistry teachers involve the learners in planning for instructional strategies $7(78 \%)(3.8)$, chemistry teachers disclosure of the specific objectives of each lesson before the commencement of the lesson 6(67\%) (3.9), chemistry teachers use instructional strategies as the preferred medium of classroom communication $6(67 \%)(3.8)$, Chemistry teachers use frequently explorative discovery in their lessons 6(67\%) (3.6), chemistry lessons uses of seminars where each student researches and presents a paper for class criticisms as the strategies to be taken by teachers $6(67 \%)(3.8)$, chemistry teachers use frequently explorative discovery in their lessons 6(67\%) (3.6), chemistry lessons uses of seminars where each student researches and presents a paper for class criticisms as the strategies to be taken by teachers 6(67\%) (3.8).

The findings are in agreement with the study done by Boa (2014) in Kilimanjaro, which revealed use of relevant text books and reference books, learner centered instructional methods and other alternative methods such as questions and answer methods, giving continuous assessments to students on time, and giving students feedback on time to enhance science subject performance. Thus, if the chemistry teachers and students apply those strategies in secondary school the performance in Chemistry could be better probably the strategies are not effectively used.

The findings from the head of schools are in agreement with the findings from other respondents on the use of heads of school's strategies to enhance Chemistry performance which revealed that most of the teaching and learning of chemistry is still done using content-based curriculum in steady of employing competence-based methods.

Finally, both students and their teachers were requested to make suggestions on how to make chemistry more meaningful and interesting, and answers were given without any response options. Both groups gave the same recommendations; first of all, they wanted more laboratory and practical work, secondly, suggested that chemistry education should be more closely connected to everyday life situations. Many students also emphasized the importance of teacher's competence and commitment to their works.

\subsection{Hypothesis Testing}

Null hypothesis was tested through spearman's correlation which aimed to determine the relationship between the two variables.

\subsubsection{Null hypothesis $\left(\mathrm{H}_{0}\right)$}

There is no significant relationship between effectiveness of strategies used by Heads of schools and student's chemistry performance in form four national examinations.

\subsubsection{Significance Level}

The null hypothesis is tested at 0.05(5\%) level of significance.

\subsubsection{Decision Rule}

If $p$ - value is less or equal to $\leq 0.05$ the Null Hypothesis will be rejected, meaning that there is a significant relationship between variables. If $p$ - value is greater or equal to 0.05 , the Null Hypothesis is accepted, implies that there is no significant relationship among variables being tested.

\subsection{The Pearson Product-Moment Correlation Coefficient}

This test was used because the hypothesis wanted to determine if there is significant relationship between the effectiveness of heads of school's strategies used in secondary schools and Chemistry performance in form four National examinations. On testing the effectiveness of the types of heads of school's strategies as perceived by student respondents were coded, analyzed and mean score of each school were calculated. Furthermore, student academic performances in Chemistry were obtained from each school in terms of Grade Point Average (GPA's). According to NECTA low GPA indicates good performance and higher GPA indicates poor performance. The researcher did reverse coding so as to let higher GPA to indicate higher performance and low GPA to indicate low performance. The researcher used students mean scores on the perceived level of effectiveness of types of heads of school's strategies as independent variable and mean score of school GPA in Chemistry subject from 2013-2017 as dependent variable that is $\mathrm{x}=$ independent variable and $\mathrm{y}=$ Dependent variable as shown in table 4.14 


\begin{tabular}{|c|c|c|}
\hline Schools & $\begin{array}{c}\text { X- Mean Scores Extent of } \\
\text { Effectiveness }\end{array}$ & $\begin{array}{c}\text { Y- Mean School Chemistry } \\
\text { GPA }\end{array}$ \\
\hline K & 4.1 & 3.1745 \\
L & 3.9 & 3.3499 \\
M & 4.0 & 3.2336 \\
A & 2.9 & 4.4455 \\
B & 3.6 & 4.4139 \\
C & 3.6 & 4.9335 \\
D & 3.6 & 4.5394 \\
E & 3.3 & 4.6299 \\
F & 3.9 & 3.8027 \\
\hline
\end{tabular}

Table 9: Mean Student Score on the Level of Effectiveness of Strategies Used by Heads of Schools in Enhancing Chemistry Performance And Mean School Chemistry Performance Source: Field Data, 2018

\subsection{Assumptions of the Test}

All the assumptions of the test were met. This was done by using statistical package for social science (SPSS). These assumptions are:

- There must be linear relationship between the variables

- The variables must be continuous

- The data for both variables must be normally distributed

- Homoscedasticity

It was assumed that $\quad x=$ the extent of effectiveness of Heads of school's strategies used and $\quad y=$ mean school Chemistry GPA.

\begin{tabular}{|c|c|c|c|}
\hline \multicolumn{2}{|c|}{} & $\begin{array}{c}\text { Effectiveness of Hos } \\
\text { Strategies in Chemistry }\end{array}$ & $\begin{array}{c}\text { Academic Performance } \\
\text { in Chemistry }\end{array}$ \\
\hline \multirow{2}{*}{\begin{tabular}{c} 
Effectiveness of the Heads of $\begin{array}{c}\text { Schools strategies in } \\
\text { Chemistry }\end{array}$ \\
\cline { 2 - 4 }
\end{tabular}} & Pearson Correlation & 1 & $.734^{*}$ \\
\cline { 2 - 4 } & Sig. (2-tailed) & & .025 \\
\hline Academic performance & $\mathrm{N}$ & 9 & 9 \\
\cline { 2 - 4 } & Pearson Correlation & $.734^{*}$ & 1 \\
\cline { 2 - 4 } & Sig. (2-tailed) & .025 & 9 \\
\hline
\end{tabular}

Table 10: The Relationship between Effectiveness of Strategies Used by Heads of Schools in Enhancing Chemistry Performance and Student Academic Performance in Chemistry

* Correlation Is Significant at the 0.05 Level (2-Tailed)

Pearson product moment correlation was computed to determine if there is a significant relationship between effectiveness of head of schools' strategies employed and the mean school chemistry GPA. Appendix 1.indicates that there is strong correlation between extent to which strategies used by heads of schools and the mean school Chemistry GPA ( $\mathrm{r}=$ 0.734) and correlation coefficient is a significant since $p$ - value 0.025 is less than 0.05 , therefore the null hypothesis was rejected which implies that there is significant relationship between the effectiveness of Head of schools strategies used and the academic performance in Chemistry. The finding implies that, when these effective strategies are frequently used by the heads of schools the performance of the school in the chemistry subject in terms of GPA could be better.

\section{Summary, Conclusions and Recommendations}

\subsection{Summary of the Study}

The study was mainly conducted to investigate the effectiveness of heads of schools' strategies in enhancing Chemistry performance in form four national examinations in Hai, district- Tanzania. The study was guided by two research questions: The following hypothesis was formulated to guide the research;

\subsubsection{Null hypothesis $\mathrm{H}_{0}$}

There is no significant relationship between heads of school's strategies to enhance Chemistry performance and chemistry performance in form four national examinations in Hai district.

\subsubsection{Alternative Hypothesis $\mathrm{H}_{\mathrm{I}}$}

There is a significant relationship between Heads of school's strategies to enhance chemistry performance and student performance in Chemistry in Form Four National Examinations in secondary schools.

The study adopted cross sectional survey and phenomenology designs under quantitative and qualitative approach respectively. The sample comprised of nine (09) secondary schools which were sampled using stratified sampling followed by simple sampling techniques to obtain three (03) private and six (06) secondary schools. 
In first research question the findings revealed that school management put in practice good leadership styles of using different tactics and strategies in classroom setting through supervisory role to ensure successful implementation of teaching and learning process. Most of heads of schools used the following strategies to enhance Chemistry performance; providing enough chemistry teaching and learning resources, provision of good Chemistry learning environment and provision of regular motivation and rewards for best performers both teachers and students in Chemistry, eensuring provision of holiday home package for Chemistry and enabling effective students assessments and evaluation in Chemistry. The magnitude of use of the strategies differs from one category of school as it depended on the level of availabilities of facilities. The findings showed that private secondary schools were better in utilizing those strategies due to better infrastructure and better financial resources contrary to their counter parts public secondary schools.

The following were effective strategies used in schools supervising teacher preparation and teaching process, hiring of enough and competent Chemistry teachers, providing counseling and guidance in chemistry. Furthermore, enabling of frequent assessment and evaluation in Chemistry, providing laboratory technician, and providing conducive learning environments. Students rated the following strategies ineffective: providing in service training for Chemistry teachers, enabling computer assisted teaching and learning in Chemistry and frequent use of visual and audio-visual teaching aids in Chemistry.

Furthermore, the findings indicate that majority of Chemistry teachers supported the following strategies to be effective as follows: frequently assisting teachers to provide much homework in chemistry, enabling conduction of remedial classes and compensating Chemistry teachers. Others were closely making follow up to enable time management for chemistry teachers and students, providing conducive teaching and learning environment in chemistry. Similarly, strategies such as providing career counseling and guidance to chemistry teachers and students, enabling of regular assessments and feedback in Chemistry and enabling availability of enough and competent chemistry teachers were rated effective. Others strategies were less effective according to chemistry teachers including computer assisted teaching and learning in Chemistry, insisting and supporting the use of audio and visual aids in teaching and learning chemistry and providing regular motivation by rewarding best performers in Chemistry. Public schools were moderately employing effective strategies in enhancing Chemistry performance as compared to private schools that were better in implementing effective strategies since they have lesser challenges. This implies that the use of effective strategies in enhancing Chemistry performance is not done to its maximum level which might also not produce maximum Chemistry performance.

In the second research question the findings revealed that lesson notes were the only materials that were prepared by majority of the teachers. Heads of school used several approaches in supervising the implementation of instructional practice Students and chemistry teachers. The findings on the use of heads of schools strategies by chemistry teachers and students to enhance chemistry performance in Form Four National Examinations revealed the following: Most of the teaching and learning of chemistry were done using content based curriculum and not competence based techniques. Respondents scored in the following: Chemistry frequent demonstrations in chemistry, conducting experiment regularly, use of cooperative learning, using computer assisted teaching and learning, frequent use of audio visual aids, use of guided discovery strategies in teaching chemistry, doing project, use of problem solving, group discussion and study tours. The strategies were not much practiced in schools due to fear of failing to cover the syllabus on time instead lecture, notes copying and question and answer were commonly used in both public and private secondary schools.

There were inconsistencies in instructional implementations supervision strategies by heads of school and uncoordinated guidance and counseling practices in the sampled schools in the study area as the findings revealed that lecture and demonstration methods were used to teach since most of the schools reported lack of laboratories, equipment and chemicals as the finding showed that, lack of adequate practical periods, inadequate laboratory facilities make the teaching of chemistry to be ineffective in most schools in the study area.

Though in private schools there was evidence of being financially better due to parents contributions to enhance teaching and learning of chemistry: there were no alternative sources of funds particular in public secondary schools to supplement the Government grants through free education initiatives in the study area hence school facilities in those schools remained un-conducive to effective Chemistry teaching and learning process.

\subsection{Conclusion}

Heads of secondary schools in Hai district uses varieties of strategies in enhancing students Chemistry performance in Form Four national examinations. Some were effective others were not. Effective strategies were: providing teaching and learning resources, provision of good Chemistry learning environment, Provision of motivation and rewards for best performers, ensuring provision of holiday home package and regular effective student assessment and evaluation. Strategies which were not effective include enabling classroom use of audio and visual teaching aids in Chemistry, ensuring in-service training and mentoring of chemistry teachers and enabling conduction of effective remedial classes. These strategies were more effectively used in private schools due to schools have enough committed and hardworking chemistry teachers, good school leadership, provides enough teaching and learning facilities, provide conducive Chemistry learning environment and frequent use of practical oriented learning.

Chemistry teachers to most cases still using content-based approaches strategies and were to some extent using learner centered approaches in classroom. Teachers used cooperative learning frequently, guided discovery strategies, jigsaw techniques, and problem-solving techniques, group discussion and student class presentation while content-based approaches included frequent lecturing and occasionally attendance to laboratory and library.

Finally, hypothesis testing showed that, there is a statistically significant relationship between students mean scores of effective strategies used by heads of schools and Chemistry academic performance in Form Four national examinations in Hai district. 


\subsection{Recommendations}

The following recommendations were made to various stake holders of education: First, in order for secondary schools to perform high in Chemistry, the Ministry of Education Science and Technology need to ensure that all secondary schools have enough motivated and qualified teachers so as to ensure effective teaching and learning for high Chemistry schools' performance. Second, all schools should have three laboratory one being for chemistry and should be furnished with necessary equipment and chemicals. Chemistry practical should be conducted along with teaching theory. Third, regular assessments of the subject should be well set, done, and the immediate feedback of the performance should be provided. Furthermore, remedial classes should be conducted. The number of students opting for There should be student industrial visits scheme and regular projects for students to broaden the knowledge and rise interest in their Chemistry learning. Fourth, Provision of guidance and counseling, career counseling for chemistry students as soon as the students enters form one should be done so as to remove the syndrome that chemistry is a difficult subject. Fifth, Seminars on crucial topics and practical preparation skills should be provided to chemistry teachers as well as curriculum supervision skills for heads of schools to enable them be effective in those areas. Sixth, the head of schools, Chemistry Teachers and student should have pleasant relationship between them. We need to make chemistry relevant to their lives. Finally, low performing schools in Chemistry should learn strategies used by nearby high performing schools such as provision of home package and evening remedial classes.

\subsection{Recommendations for Further Studies}

The researcher recommended further studies to be conducted to address the following issues:

- Effectiveness of heads of school strategies to enhance Chemistry performance in form two National assessment examinations in Public secondary schools.

- There is a need to conduct a study on effectiveness of school administration to enhance student choice of chemistry in form three in secondary schools.

\section{References}

i. Abudu, K. A. \& Gbadamosi, M.R. (2014). Relationship between teacher's attitude and student's academic achievement in senior secondary school chemistry. A case study of Ijebu-Ode and Odogbolu Local Government Area of Ogun state. Wudpecker Journal of Educational Research ISSN 2315-7267 Vol. 3(3), pp. 035 - 043, April 20142014 Wudpecker Journals.

ii. Adesoji F.A., Olatunbosun S., (2008). Student, Teacher and School Environmental factors as Determinants of Achievement in Senior Secondary School Chemistry in Oyo State, Nigeria. The Journal of International Social Research.

iii. Apolline T. A. (2014). Motivational Strategies used by Principals in the Management of Schools. The Case of some Selected Secondary Schools in the Fako Division of the Southwest Region of Cameroon.

iv. Ayeni A. J. \&Akinfolarin C. A. (2014). Assessing Principals" Coordinating and Controlling Strategies for Effective Teaching and Quality Learning Outcome in Secondary Schools in Ondo State, Nigeria. International Journal of Learning, Teaching and Educational Research. Vol. 7, No. 1, pp. 180-200, August 2014.

v. Bamiro, A.O. (2015). Effects of Guided Discovery and Think -pair- share Strategies on Secondary Schools Students Achievement in Chemistry. Retrieved from (http:// www.uk.sagepub. com/ aboutus/ openaccess.htm) on 29th March, 2018.

vi. Boa Y. (2014). Determinants of High Academic Performance in Secondary schools in Kilimanjaro Region. Open University of Tanzania.

vii. Brunner, J.S. (1966). Towards a theory of Instruction. Cambridge, MA, Harvard University Press.

viii. Chepkorir, S., Cheptonui, E. M. \& Chemutai, A. (2014). The Relationship between Teacher-related factors and Students' Attitudes towards Secondary School Chemistry Subject in Bureti District, Kenya. Journal of Technology and Science Education. Vol. 4(4). 2014

ix. Galabawa, J.C.J. (2001). Perspectives in Educational Management and Administration, KAD Associates/TFC; Dar es Salaam [accessed June 05 2018]

x. Hassan, A. (2011). Factors affecting student performance in Chemistry: A case of Zanzibar Secondary schools. International journal of Educational and pedagogical Sciences.

xi. Kanno, Y. (2007). ELT Policy directions in multilingual Japan: International Handbook of English language teaching. New York: Springer.

xii. Martel, H. A. (2009). Effective Strategies for General and Special Education Teachers.

xiii. Mestry, R. (2017). Principals' Perspectives and Experiences of their Instructional Leadership Functions to Enhance Learner Achievement in public schools. Journal of Education 69 Durban 2017

xiv. Ministry of Education and Vocational Training (MoEVT), (2011). Secondary education development programme II, final draft July 2010-June 2015. Dar es Salaam: MoEVT.

xv. MoEVT, (2013). School Improvement Toolkit: Practical Guide for Head teachers and Heads of Schools: Dar -Es- salaam

xvi. Mugambi, M. D., (2015). Exploring Reading Habits and Academic Success in Rural Kenya.

xvii. Musungu L.L, Kasandi, A.J.S., Wamochamasinde N.J. (2008). The Motivational Strategies used by Head teachers in Academic Achievement in Secondary Schools in Vihiga district, Kenya. The problem of education in 21st century vol. 8. 2008.

xviii. Mususya, J. (1992). The relationship between the Mastery of facts and concepts in science among standard seven boys and girls in Nzeluni Educational zone in Mwingi division, Kitui District. Unpublished Med thesis Kenyatta University.

xix. Mwangi J.T. (2016). Effect of Chemistry Practical's on Students' Performance in Chemistry in Public Secondary Schools of Machakos and Nairobi counties in Kenya. Doctorate Research thesis in Chemistry, School of Education University of Nairobi. 
xx. Norviewu-Mortty, E.K. (2012). Principals' Strategies for Improving the Academic Achievement of Students of Disadvantaged Rural Junior High Schools in Ghana.

xxi. Out \& Avaa A. (2007). Improving Performance in the Sciences. A Support Paper Presented at a Workshop held at Federal Government Girls' College Zaria, 2007.

xxii. Ronald, B. \& Frank well, D. (2014). Assessment of Access and Use of school Library Information Resources by Secondary Schools Students in Morogoro, Tanzania.

xxiii. Shemhilu, T.S. (2015). Factors Affecting Chemistry Performance in Ordinary Level NECTA Examinations from 20052012.A case of selected schools in Dar-es-salaam. Master thesis-Open University of Tanzania.

xxiv. Tenaw, Y.A. (2013). Relationship of Students' Attitude and Achievement in Chemistry with Teacher's Classroom Management.Journal of Elementary Education Vol.23, No. 2

xxv. UNESCO (2005). Education for All (EFA) Global monitoring report. The role of the organization and social context of schools. http:// portal.org/ education.

xxvi. World Bank, (2010). Recruiting, retaining, and retraining secondary school teachers and principals in Sub-Saharan Africa. Washington DC: The World Bank.

\section{Appendix}

\begin{tabular}{|c|c|c|c|c|c|c|c|c|c|c|}
\hline \multirow[t]{2}{*}{ School } & \multirow[t]{2}{*}{ Year } & \multirow{2}{*}{$\begin{array}{l}\text { No. cand } \\
\text { all subj }\end{array}$} & \multirow{2}{*}{$\begin{array}{c}\text { No cand } \\
\text { opted Chem }\end{array}$} & \multirow{2}{*}{$\%$} & \multicolumn{2}{|c|}{ Pass rate (\%) } & \multicolumn{2}{|c|}{ Failure rate (\%) } & \multirow{2}{*}{$\begin{array}{c}\text { X-School } \\
\text { Effectiveness } \\
\text { mean score }\end{array}$} & \multirow{2}{*}{$\begin{array}{c}\text { Y-School } \\
\text { Chem GPAs }\end{array}$} \\
\hline & & & & & $\begin{array}{l}\text { Grade A- } \\
\text { C }\end{array}$ & $\%$ & Grade D-F & $\%$ & & \\
\hline \multirow{5}{*}{$\mathbf{K}$} & 2013 & 59 & 55 & 93.2 & 39 & 70.9 & 16 & 29.1 & \multirow{5}{*}{4.1} & 3.8966 \\
\hline & 2014 & 68 & 54 & 84.3 & 43 & 79.6 & 11 & 20.4 & & 2.2667 \\
\hline & 2015 & 62 & 32 & 51.6 & 27 & 84.4 & 05 & 15.6 & & 2.9394 \\
\hline & 2016 & 53 & 44 & 83 & 15 & 34.1 & 18 & 65.9 & & 3.5152 \\
\hline & 2017 & 45 & 45 & 100 & 39 & 86.7 & 06 & 13.3 & & 3.7727 \\
\hline \multirow{5}{*}{$\mathbf{L}$} & 2013 & 74 & 33 & 44.6 & 33 & 100 & 00 & 00 & \multirow{5}{*}{3.9} & 3.1212 \\
\hline & 2014 & 82 & 35 & 42.7 & 35 & 100 & 00 & 00 & & 3.0213 \\
\hline & 2015 & 84 & 41 & 48.8 & 41 & 100 & 00 & 00 & & 2.6829 \\
\hline & 2016 & 79 & 44 & 55.7 & 31 & 70.5 & 13 & 29.5 & & 3.2273 \\
\hline & 2017 & 100 & 43 & 43 & 34 & 79.1 & 09 & 21.9 & & 3.1628 \\
\hline \multirow{5}{*}{ M } & 2013 & 70 & 37 & 52.9 & 34 & $\begin{array}{l}91.9 \\
\end{array}$ & 03 & 8.1 & \multirow{5}{*}{4.0} & 3.4210 \\
\hline & 2014 & 84 & 46 & 54.8 & 46 & 100 & 00 & 00 & & 2.7174 \\
\hline & 2015 & 64 & 40 & 62.5 & 39 & 97.5 & 01 & 2.5 & & 2.7250 \\
\hline & 2016 & 86 & 49 & 60 & 24 & 50 & 25 & 50 & & 3.4694 \\
\hline & 2017 & 81 & 40 & 49.4 & 14 & 35 & 26 & 65 & & 3.6250 \\
\hline \multirow{5}{*}{ A } & 2013 & 51 & 30 & 58.8 & 08 & 26.7 & 22 & 73.3 & \multirow{5}{*}{2.9} & 5.2667 \\
\hline & 2014 & 34 & 24 & 70.6 & 14 & 58.3 & 10 & 41.7 & & 5.1471 \\
\hline & 2015 & 45 & 26 & 57.8 & 07 & 26.9 & 19 & 63.1 & & 3.9231 \\
\hline & 2016 & 105 & 16 & 15.2 & 08 & 50 & 08 & 50 & & 3.7143 \\
\hline & 2017 & 112 & 14 & 12.5 & 05 & 35.7 & 09 & 64.3 & & 3.158 \\
\hline \multirow[t]{5}{*}{ B } & 2013 & 203 & 69 & 33 & 09 & 13 & 58 & 87 & \multirow{5}{*}{3.6} & 4.4565 \\
\hline & 2014 & 53 & 52 & 8.1 & 14 & 26.9 & 38 & 73.1 & & 4.2308 \\
\hline & 2015 & 149 & 90 & 60.4 & 11 & 12 & 71 & 88 & & 4.3212 \\
\hline & 2016 & 118 & 42 & 5.6 & 06 & 14.3 & 18 & 85.7 & & 4.2100 \\
\hline & 2017 & 105 & 34 & 2.4 & 03 & 8.8 & 31 & 91.2 & & 4.4706 \\
\hline \multirow{5}{*}{ C } & 2013 & 64 & 20 & 1.3 & 02 & 10 & 18 & 90 & & 4.6232 \\
\hline & 2014 & 70 & 23 & 2.9 & 09 & 26 & 14 & 74 & & 4.565 \\
\hline & 2015 & 61 & 26 & 2.6 & 02 & 7.7 & 24 & 92.3 & 3.6 & 4.5436 \\
\hline & 2016 & 87 & 19 & 1.8 & 02 & 10.5 & 17 & 89.5 & & 4.4211 \\
\hline & 2017 & 45 & 18 & 40 & 04 & 22 & 12 & 88 & & 4.5455 \\
\hline & 2013 & 73 & 17 & 3.3 & 01 & 5.9 & 18 & 93.1 & & 6.0588 \\
\hline D & 2014 & 16 & 16 & 100 & 01 & 6.3 & 15 & 93.7 & & 5.6342 \\
\hline & 2015 & 56 & 09 & 16.1 & 00 & 00 & 09 & 100 & 3.6 & 4.889 \\
\hline & 2016 & 50 & 14 & 28 & 02 & 14.3 & 12 & 85.7 & & 4.2143 \\
\hline & 2017 & 36 & 05 & 13.9 & 01 & 20 & 04 & 80 & & 4.00 \\
\hline $\mathbf{E}$ & 2013 & 61 & 15 & 6.7 & 01 & 6.7 & 14 & 93.3 & & 4.6992 \\
\hline & 2014 & 38 & 37 & 97.4 & 00 & 00 & 37 & 100 & & 4.1111 \\
\hline & 2015 & 67 & 37 & 55.2 & 05 & 13.5 & 32 & 86.5 & 3.3 & 4.5517 \\
\hline & 2016 & 69 & 18 & 26.9 & 03 & 16.7 & 15 & 83.3 & & 4.5517 \\
\hline & 2017 & 37 & 37 & 100 & 00 & 00 & 37 & 100 & & 4.7027 \\
\hline & 2013 & 65 & 19 & 29.2 & 03 & 15.8 & 16 & 84.2 & & 3.8673 \\
\hline & 2014 & 55 & 21 & 38.2 & 07 & 33.3 & 14 & 66.7 & & 4.2863 \\
\hline $\mathbf{F}$ & 2015 & 64 & 20 & 31.3 & 02 & 10 & 18 & 90 & 3.9 & 4.4352 \\
\hline & 2016 & 51 & 16 & 31.4 & 03 & 18.8 & 13 & 81.2 & & 4.1875 \\
\hline & 2017 & 43 & 18 & 41.9 & 06 & 33.3 & 12 & 66.7 & & 3.6111 \\
\hline
\end{tabular}

Table 11: Hai District Schools Chemistry Enrolment \& Performance in National Examinations - 2013-2017.Source: (NECTA \& FIELD DATA) 